\title{
Of Parochial Partisanship and Education: Towards Civic Duty or Polarization?
}

\author{
George Asekere ${ }^{1} \&$ Ebenezer Teye Amanor-Lartey ${ }^{1}$ \\ ${ }^{1}$ Department of Political Science Education, University of Education, Winneba, Ghana \\ Correspondence: George Asekere, Department of Political Science Education, University of Education, Winneba, \\ Ghana. E-mail: georgeasekere@gmail.com
}

Received: September 22, 2021

Accepted: October 27, $2021 \quad$ Online Published: October 29, 2021

doi:10.5539/jpl.v15n1p7

URL: https://doi.org/10.5539/jpl.v15n1p7

\begin{abstract}
This article explored parochial partisanship among university students amid growing concerns about political polarization in Ghana. The paper used mixed research methods to gather data with the aid of an interview guide and a questionnaire. It argued that university education inculcates in and endows young people with a sense of civic-minded duty to prioritize the collective good of society and subordinate parochial partisan preferences in an analysis of political policies. The novel finding is that university education in Ghana has enlightened many young people to decipher between the facts and the propagandistic view held by political activists because of parochial partisan interest. However, university education was found to be a necessary but not sufficient condition to wipe out parochial partisanship which is the bane behind the growing political polarization in Ghana. The paper recommends continuous seminars on the dangers associated with negative partisanship in all tertiary educational institutions. Further, the winner-takes-all politics should be reviewed.
\end{abstract}

Keywords: education, civic duty, partisanship, polarization, Ghana

\section{Introduction}

Despite its enviable accolade as one of the beacons of democracy in West Africa, public commentary in Ghana suggests that the country is highly polarized along parochial partisan lines. This is further exacerbated by the winner-takes-all politics being practiced in the country where a victorious political party and its members are treated as citizens while all others are dealt with as helpless spectators. Partisanship, as used in this article, refers to an attachment to a political party to an extent that the party's policy stance, attitudes, evaluation of socio-political and economic issues, and electoral behaviour, influence one's position in a directional manner (Samuels, 2006). In other words, self-identification to a party such that it "structures one's cognitive understanding of politics" even amid superior policy positions (Miller \& Klobucar, 2000, p. 675). The focus on partisanship in Ghana is vital because parochially motivated partisanship is generally believed to be behind the growing polarization in Ghana. Parochial-partisanship in this context is, therefore, an extreme form (negative) of party identification, and not necessarily being partisan over strong views such as democracy as opposed to other undemocratic forms of government. As such, partisanship aimed at nurturing democratic consciousness in the masses is great (Lippman, 1993). However, it becomes problematic when policy positions are subordinated to parochial-partisan interest. In Ghana, there is growing public consensus that one needs to show evidence of being partisan and aligned to the ruling party to get preferential treatment including escaping lawful punishment by the state security agencies. For instance, the government in 2020 rejected a recommendation by a Commission of Inquiry to sanction a known ruling party thug who slapped an opposition Member of Parliament (MP), but rather argued that the MP provoked the thug (Emile Short Commission of Inquiry Report, 2020).

As such, it looks safe for people to want to be partisan and align themselves to the two leading political parties, the National Democratic Congress (NDC) and the New Patriotic Party (NPP), which have alternated political power since 1992. Partisanship is a necessary, though not sufficient condition, for political attitude formation in every society (Campbell et al., 1954). However, when people become overly partisan at the expense of civic duty, it has implications on polarization which negates efforts at building a democratic society where meritocracy takes precedence over partisan driven nepotism and patronage. When a considerable weight is given to a party's endorsements in information processing or policy position (Druckman, 2012) such that NPP legislators or elites support a policy proposed by the NPP, but oppose the same policy if proposed by the NDC, it could be interpreted 
to mean a normal action in multi-party politics. The same cannot be said when the governed who are supposed to hold the government accountable in democratic politics tends to look at every issue with polarized partisan lenses motivated by parochial interest.

The winner-takes-all politics in Ghana has motivated many, especially the uneducated class, to take negative partisan positions on almost all national and local issues, sometimes at the detriment of their lives. Such partisan attachment (sometimes distorted) due to inadequate knowledge or illiteracy has caused the lives of many young people in Ghana because they wanted to 'die at all cost' for their political parties. A sense of civic duty which Mullinix (2018, p.199) believes has "salubrious effects for opinion formation by dampening partisan distortions in decision making" can potentially reduce the worse effects of partisanship, especially the type induced by illiteracy in Ghana. Civic duty is thus conceptualized minimally in this paper to mean an amalgamation of civic norms and expectations that places national interest above parochial partisan consideration (Blais, 2000). A sense of civic duty should propel people to consider policy positions or information objectively and mitigate partisan distortions (Mullinix, 2018). University education entails the provision of a diverse combination of particularized and collective incentives (Dar \& Lee, 2014). The outcome is a great potential to contribute to the development of one's country by being guided to subordinate partisan interest to the national interest. Given the varieties of constituencies served, inconsistencies relative to the link between partisan interest and education are to be expected. As such, it should not be a major issue for Democrats, in the US, to support redistribution policies than Republicans or Republicans oppose same-sex than Democrats. Both Parties support, for instance, spending on community colleges because of the perceived collective benefit/good to society (Dar \& Lee, 2014). In the case of Ghana, the polarization cuts across every issue hence, any policy proposed by one party is opposed by the other due to parochial interest. Illiteracy and joblessness have been blamed for the negative partisanship among the youth, especially the uneducated who sometimes go to the extent to physically attack people who share contrary views on policies. It is within this context that the paper explores the impact of university education on young people's capacity to be pragmatic and issue-based partisans; not parochially motivated partisans.

The extant literature on Ghanaian politics has variously drawn a link between gender and political participation (Bauer, 2019; Asekere \& Braimah, 2021), rationality and voting behaviour (Alidu \& Aggrey-Darkoh, 2018), political parties, and vigilantism (Adzimah-Alade et al., 2020; Asamoah, 2020), the link between tribal politics and conflicts (Debrah et al., 2016), local government and enhanced participation (Amponsah \& Boafo-Arthur, 2002; Ayee, 1990), winner-takes-all and violence (Abotsi, 2013; Gyampo, 2015) as well as the youth and politics (Debrah \& Gyampo, 2013).

However, little attention has been given to the link between university-level education and parochial partisanship in Ghana. The paper contributes to the literature by exploring the extent to which university students who are deemed future leaders can subordinate parochial interests and conform to "societal norms of pragmatism over partisanship" as a civic duty (Groenendyk, 2013, p. 110).

To do this, the paper draws on Taber and Lodge's (2006) criterion for motivated opinion formation in party politics: directional and accuracy goals. The former refers to when a person's party identification motivates him/her to arrive at a particular skewed conclusion. Such a conclusion is based on partisan directional goals, deemed parochial in this paper. Directional goals are, therefore, aimed at protecting one's partisan identification. The latter (accuracy goals) is when people are motivated to assess information in a manner that will likely lead to an accurate or balanced opinion. In other words, forming a correct political opinion is when people "evaluate political arguments with the hope of reaching an outcome that is the "correct or otherwise best conclusion", deemed national interest in this paper (Taber and Lodge 2006, p. 756). Given the difficulty in measuring correct opinion, the paper assumes that people will less likely engage in "partisan motivated reasoning when pursuing an accuracy goal in the opinion formation process" irrespective of their political affiliation or identity (Bolsen et al., 2014, p. 239). Based on this, we theorize that education up to the university level has the propensity to drive students to evaluate information in a way that will lead to an objective (correct) opinion devoid of parochial or negative partisan attachment (Kunda, 1990). In other words, the paper argues that education up to the university level would propel a heightened sense of civic duty which can dampen partisan-induced distortions of information and prioritize national interest/civic duty above political party identity. This view is in line with the assertion that schools are significant communities for fostering strong civic norms and impact individuals' civic engagement (Campbell, 2006). Besides, studies on partisanship suggest that demographic variables such as age and level of education "can be associated with stronger or weaker tendencies for citizens to acquire partisanship"(Samuels, 2006, p. 9).

The paper proceeds as follows: The introductory section is followed by a review of empirical and theoretical literature. The next section is a note on the methodology used in conducting the study. This is followed by the findings and discussions. The final part is the conclusion and recommendations. 


\section{Review of Related Literature}

The theoretical link between civic norms/national interest, education, and partisanship has been variously explored by scholars (Blanc, 2008; Campbell et al., 1954; Groenendyk, 2013; Mullinix, 2018; Strömblad \& Bengtsson, 2017). It is argued that partisanship - the degree to which people feel attached to a political party- may help in nurturing democracy (Lupu, 2015). On the other hand, partisanship that takes the form of 'they' against 'us' breeds acrimony, tensions, and polarization; the kind described in this paper as parochial. Ordinarily, Lupu (2015) held that when political parties agree on policies they become less competitive. Disagreement is, therefore, not the problem since it is central in democracy. The challenge is when partisanship leads to bitter polarization which eventually undermines the very essence of democracy. It is the position of this paper that citizens who are motivated by civic norms or duty by virtue of education may less likely be negatively partisan, and thus contribute to less polarization.

Dalton (2008) described civic duty as a "shared set of expectations about the citizen's role in politics" including "what people think people should do as good citizens" (Dalton, 2008, p. 78). This plays a role in how people process or assess information, whether motivated by parochial partisan (directional goals) or national interest (accuracy goals) which, we argue reflects civic norms. When civic norms are prioritized, negative partisanship will be reduced, hence polarization will be minimized. According to Campbell (2006), the degree to which people feel a sense of civic obligation stems, partly, from their adolescent experience. Campbell opined that high school education impacts individuals' civic involvement which could remain over a decade after graduation. Groenendyk (2013, p.111) examined the willingness of people to update their partisanship in response to the national interest and noted that even partisans may update their "identity because they feel it is their civic duty to conform to societal norms of pragmatism over partisanship" and the "expressive benefits that come from seeing oneself as a pragmatic citizen, which is an aspect of civic duty". Civic duty or norms influenced by education can potentially reduce polarization caused by negative partisanship.

Dalton (2008) and Groenendyk (2013) identified four yardsticks in assessing civic norms: participation, autonomy, social order, and solidarity. Participation refers to the importance attached to issues such as political socialization, political activism, and voting. Autonomy describes the extent to which citizens are adequately informed about what goes on in the body politic and be able to freely participate and tolerate the views of others. Warren discussed autonomy, in the context that "preferences should not be the result of manipulation or received opinion but rather the result of considered adherence"(Warren, 2001, p. 60). According to Dalton, social order is the willingness of people in democratic states to accept state authority and obey laws. Solidarity refers to the moral and ethical responsibility people have for each other (Dalton, 2008). It is the considered view of the authors, that these constitute the national interest, at least for this study.

The Directive Principles of State Policy contained in chapter six of the Constitution of Ghana provides the framework for civic responsibility. Such includes the duty of a citizen to uphold and defend the Constitution; to foster national unity and live in harmony with others; to respect the rights, freedoms, and legitimate interests of others, and generally to refrain from doing acts detrimental to the welfare of other persons; to work conscientiously in his lawfully chosen occupation; to protect and preserve public property and expose and combat misuse and waste of public funds and property (Republic of Ghana, 1992). Inherent in the above is an educational objective that enjoins the state to prioritize. This, notwithstanding, partisan supporters of victorious political parties (mostly the uneducated) in Ghana, have in countless times, taken the law into their own hands and forced people in lawful positions including the civil service out of their offices on grounds that such did not support the party's struggle to capture power. These actions, considered negative partisanship based on parochial interest, have been tacitly endorsed by the political parties through their response to such unlawful actions by their supporters. For instance, in 2017, when supporters of the ruling party stormed the Law Court, assaulted the trial judge, and freed their colleagues standing trial for unlawfully assaulting the Ashanti Regional Security Coordinator, party executives who are lawyers defended the thugs in court. When they were eventually fined, party executives paid for them and held a press conference to announce it. Such conduct does not fit the description of civic duty, which the educational objective contained in Ghana's constitution mandates the state to promote (Republic of Ghana, 1992). Regardless, political parties in Ghana endorse the actions of followers because these are the people who support the policy positions of the parties during electioneering (Bob-Milliar, 2014).

The dominant literature is replete with arguments that tilt in favour of the view that partisans in every society would ordinarily be supportive of their preferred political party's position on policies (Druckman et al., 2013). In other words, when an individual hears a "recognizable partisan source advocating some position, his partisan leanings are activated, which in turn leads him or her to evaluate the message through a partisan lens" (Goren et al., 2009, p. 806). Whenever people resort to partisan motivated reasoning, there appears some element of biases 
either in the form of counterargument or disconfirmation (Taber et al., 2009). Partisan motivated or what Taber and Lodge (2006) called a directional goal, has the potential to make people miss out on some relevant assessment of information that might otherwise be helpful to society (Druckman et al., 2013). In developing democracies such as Ghana where the illiterate population is more than the literate, parochially-induced partisan motivated reasoning or positions on policies or decisions tend to be inimical because such dents the efforts at ensuring accountability by the rulers. Besides, it leads to polarization. It is even more serious when illiterate foot soldiers are engaged in it. The evidence suggests that such foot soldiers use all means to get their 'distorted' messages across and would do everything humanly possible to mute dissenting views (Alhassan et al., 2019).

Mullinix (2018, p. 202) asserts that if the political environment "accentuates a sense of civic duty, partisan motivated reasoning should be diminished". However, when made salient, the civic duty would catalyze a more open-minded position on information and inform non-partisan reasoning. If this pertains, citizens would be focused on the substantive policy information and be less inclined to engage in parochial partisanship (Mullinix, 2018). This means that when a sense of civic duty is prioritized, people who engage in partisanship would less likely follow their political party's positions blindly. In the context of Ghana, the political environment is already polarized along with parochial partisanship. This makes it fertile for the people especially the politically unenlightened class to place their political party's position over all others, irrespective of whether the position is popular or unpopular. This has become endemic. People who are determined to be accurate "expend more cognitive effort on issue-related reasoning, attend to relevant information more carefully, and process it more deeply, often using more complex rules"(Kunda, 1990, p. 481). University education can be helpful in this context. As such, we theorize that young students being trained in universities should be able to reverse parochial partisanship because they are more exposed to the importance of civic duty and the dangers of being overly partisan. For Mullinix (2018), partisans who are minded of their civic duty are less likely to get themselves entangled in partisan motivated reasoning at the expense of the national interest. Taber and Lodge (2006) share this view. They opined that whenever people engage in politically motivated partisan reasoning, their opinions against a policy or decision become distorted in a way that leads to a polarized position (Taber \& Lodge, 2006).

The causes of parochial or negative partisanship, as against, partisan participation in politics which can nurture democratic consciousness among the masses, can be explained by various theories. The rational choice, psychological, sociological, party identity as well as civic voluntarism theories have all been advanced to explain political participation and the motives behind why people do what they do in politics. However, it is the considered view of the authors that the appropriate theory for this paper is the General Incentive Theory which came out from the seminal work of Clark and Wilson (1961). It has been argued that "no one can study political motivations without reckoning with the Clark and Wilson typology, which remains the dominant conceptual framework in this area of analysis" (Costantini \& King, 1984, p. 81). A cursory look at how people identify with their political parties and sometimes take overly partisan positions in a do-or-die manner in the case of Ghana makes this theoretical view worth considering.

The genesis of the General Incentive theory was an effort to help find an explanation to the incidence of highintensity types of political participation in the form of activities such as canvassing for votes and attending political party meetings. High-intensity participation refers to a "way of meeting like-minded and interesting people, and for some party members, this is enough motivation to get them involved in political participation" and develop a deep attachment to the party's position on everything (White \& Seyd, 2002, p.51-52). This means that people who are engaged in political party activism need some incentives to enable them to take part in politics but they need to "consider a wider array of incentives" than those narrowly identified in the Rational Choice Theory and these incentives can be found within political parties" (White \& Seyd, 2002, p.52)

According to Clark and Wilson, the internal and external activities of people in political parties can be explained by comprehending the incentive systems (Clark \& Wilson, 1961). To them, every organization needs to provide some tangible or intangible incentives to motivate members to work hard. However, no organization or party should have an incentive package or system in which it cannot sustain or even afford (Clark and Wilson, 1961). The question that arises is how do political parties sustain the maximum zeal of supporters who are so attached to the parties without corresponding resources especially when not in government? The theory assumes that effective leadership can sustain partisan supporters with great attachment. In other words, responsible leadership can achieve more success in political organizations. This can be done by working assiduously to obtain a net surplus of incentives and distribute these incentives to entice or boost the morale of the followers. The incentives, we argue, can motivate some people to be negative partisans.

Three different kinds of incentives for participation have been identified by the proponents of this theory. The first refers to material incentives such as money or any other reward that can be converted into monetary value. The 
followers get motivated by this form of tangible rewards. The second incentive is termed solidary incentives. This category of incentives is intangible rewards. As such, the followers are intrinsically motivated by loving the purpose of socialization and fully defending the position of the association (political party). The third incentive is referred to as purposive incentives. It is also an intangible incentive and results mainly from the stated outcome, such as the attainment of political objectives (Clark \& Wilson, 1961).

Clark and Wilson further argued that "individuals become contributors expecting the organization (party) to satisfy their material motives" largely because the followers understand the benefits that come with their effort at getting the party to succeed (Clark and Wilson, 1961, p. 146). In the Ghanaian context where victorious political party supporters rush to take over toll booths, public toilets, National Health Insurance Offices, Youth Employment Agencies among others, with impunity, partisan supporters certainly have a motivation for their activism.

Whiteley and Seyd (2002) posited that the General Incentives theory is simply a "blend of the rational choice and the social psychological theories of political participation" (Whiteley \& Seyd, 2002, p. 51). In effect, people are moved to engage in political participation through incentives. The emphasis on selective incentives is essential in explaining the motivation behind political activism (Bob-Milliar, 2012). The incentives which may drive partisanship and lead to polarization can take the form of 'processes', 'outcome', and 'ideological' (Whiteley 996, p. 219). The process incentives constitute the goals that individual members have for joining political parties and are not rooted in outcomes of collective action but instead in the process of participation itself. This implies that individuals can be motivated to be active because they enjoy party politics for its sake. The outcome incentives refer to rewards such as paid jobs and elective office. The ideological incentive is about the desire of the individual to interact with like-minded people (Whiteley 996, p. 219). But in all these, the need to be accurate, backed by the empirical and theoretical literature, is the motivation of this article. As noted, people who are motivated to be accurate while being partisans "expend more cognitive effort on issue-related reasoning, attend to relevant information more carefully, and process it more deeply, often using more complex rules"(Kunda, 1990, p. 481).

In effect, the theoretical and empirical scholarship on partisanship, civic norms, and political participation exist and incentives -monetary or other forms of reward - are behind the support base. However, beyond the geographical dearth and the methods used, previous studies have not paid particular attention to the extent to which university education negates parochial partisanship and equips students to be more pragmatic and independent in their assessment of policies, as a contribution to the sustenance of democracy in Ghana. This paper contributes and extends the literature in this regard.

\section{Methods and Materials}

To determine whether students were engaged in an evidence-based partisan motivated analysis of issues, the paper relied on the mixed methods to gather and analyze empirical data. Mixed methods research refers to a combination of both qualitative and quantitative research methods, techniques, concepts, approaches, and language into a single study (Creswell, 2014; Yin, 2006). Qualitative and quantitative researchers both focus on the individual's perspective and so were chosen because of the benefit of relative ontology and subjective epistemology (Denzin $\&$ Lincoln, 2005). The qualitative method provided the researchers the opportunity to use open-ended questions, in gathering data, without predetermined responses while quantitative data enabled the researchers to include closed-ended questions to seek the views of as many people as possible (Creswell, 2014).

The concurrent triangulation approach was relied upon to gather both qualitative and quantitative data concurrently and then compare the two databases to determine whether there is confirmation, disconfirmation, difference, convergence, or some combination of a sort (Creswell \& Creswell, 2017). This is vital because the study aimed at assessing whether university students are motivated by parochial partisanship interest in interpreting or analyzing political issues. The weight between the two methods was deemed complementary, to offset the weaknesses inherent within one method with the strengths of the other. In other words, the strength of one method adds to the strength of the other.

The population of the study was all public university students in Ghana, totaling about 400,000 . Both probability and non-probability sampling methods were used to select respondents. For the non-probability sampling, the purposive sampling technique was used to select 10 students: two each from the University of Ghana, Legon, University of Education, Winneba, University for Development Studies, Tamale, University of Cape Coast, and the Kwame Nkrumah University of Science and Technology, Kumasi. A non-directive style interview guide with open-ended questions that allowed the participants the freedom to answer the questions, was used (Maisey et al., 2008).

The quantitative data was gathered through a probability sampling strategy. The simple random sampling technique was used to gather data from 400 respondents, using the Yamane formula. The procedure below provides a 
simplified way to calculate sample sizes (cited in Israel, 1992, p. 4).

The Yamane formula is given as $n=\frac{\mathrm{N}}{\mathrm{N}+1(\mathrm{e}) 2}$

Total number of university students' population in Ghana $=400,000$

The researchers worked with a $95 \%$ confidence level; $5 \%$ margin of error because this is a strong precision (Israel, 1994).

Therefore:

$\mathrm{N}=400,000$

$\mathrm{e}=0.05(5 \%)$

$\mathrm{n}=400,000 /\left(1+400,000(0.05)^{2}\right.$

$\mathrm{n}=400,000 / 1+400,000(0.0025)$

$\mathrm{n}=400$; total sample size for qualitative data.

Both qualitative and quantitative methods were deployed because "neither was deemed individually necessary nor individually sufficient for an outcome" since there are multiple paths to an outcome (Mahoney \& Goertz, 2006, p. 232).

Secondary data came from journal articles, books and book chapters, and credible media publications.

The research questions focused on two major topical political issues which have attracted the news headlines and received wide publicity in both traditional and social media in Ghana. The first was free secondary school education where the NDC argued should be progressively implemented by first providing adequate infrastructure while the NPP held that the conditions were rife giving existing infrastructure and the level of poverty among Ghanaians. The second was Local Government Election where the NDC's position was that Assembly Members should be elected, but not on partisan lines while the NPP argued that the Local Government elections were already polarized along partisan lines hence Assembly Members should be elected on partisan lines.

Analyses of the data collected in this study were guided by both qualitative and quantitative techniques. The quantitative data was analyzed with the aid of SPSS (version 20) and the results were presented in tables, charts, and percentages, while the qualitative data was thematically analyzed. The themes were related to the research questions and interpreted in line with Taber and Lodge's (2006) criterion of assessing directional or correct goals in partisan information.

\section{Results and Discussions}

Partisan motivated reasoning implies that people seek out information that either reinforces their preferred political party's positions or merely for political equalization (Mullinix, 2018). At the same time, they counter-argue or oppose any issue that challenges the position of the party they support irrespective of facts. A person's exposure to a political party may be enough motivation to embrace partisan endorsements of issues that can trigger partisan distortions of information processing (Bolsen et al., 2014; Mullinix, 2018). As such, we found that partisan motivated respondents were supportive of their party's stands or position on the issues the paper assessed. On the other hand, it emerged that respondents who were motivated by a sense of civic duty were less partisan in endorsing or opposing the issues assessed.

\subsection{Results and Discussions}

In this section, we explore whether university education propels students to be civic-minded by dampening partisan-induced distortions of information on political party decisions or policies. The section presents the findings and analysis of the data collected. we blended the presentation of the findings with discussions of the empirical and theoretical literature.

\subsection{Gender, Age, and Political Affiliation of Respondents}

Analyses of the demographic data show that out of 400 respondents, $72 \%$ were males while $28 \%$ were females (Table.1) 
Table 1. Gender distribution

\begin{tabular}{crrrr}
\hline \multicolumn{5}{c}{ FrequencyPercentValid } \\
\hline Female & 112 & 28.0 & 28.0 & 28.0 \\
ValidMale & 288 & 72.0 & 72.0 & 100.0 \\
Total & 400 & 100.0 & 100.0 & \\
\hline
\end{tabular}

Source: Field survey data, $2021(\mathrm{~N}=400)$.

The implication of the gender data is that; the overall findings reflect the views of more males. In terms of the age distribution of the respondents, it emerged that $62.5 \%$ of the respondents were between the 18-24 age group, $27.8 \%$ between the 25-30 age group, $6.5 \%$ between the $31-35$ age group, and 3.3\% were between $36-40$ years (Table. 2 ).

Table 2. Age distribution of respondent

\begin{tabular}{|c|c|c|c|c|c|}
\hline & & Frequency & Percent & Valid Percent & Cumulative Percent \\
\hline \multirow{5}{*}{ Valid } & $18-24$ & 250 & 62.5 & 62.5 & 62.5 \\
\hline & $25-30$ & 111 & 27.8 & 27.8 & 90.3 \\
\hline & $31-35$ & 26 & 6.5 & 6.5 & 96.8 \\
\hline & $36-40$ & 13 & 3.3 & 3.3 & 100.0 \\
\hline & Total & 400 & 100.0 & 100.0 & \\
\hline
\end{tabular}

Source: Field survey data, $2021(\mathrm{~N}=400)$.

It is clear from the table that the majority of respondents were under 30years. This is important because these young people are most likely to retain or grow up with what they learn at this stage. In other words, if young people inculcate the habit of analyzing or interpreting information based on civic norms and not parochial partisan interest, they would most likely grow with it. Besides, as many as $71 \%$ indicated that there were members or sympathizers of political parties, hence their formative analysis of issues is very important (Table.3).

Table 3. Do you consider yourself a strong advocate/supporter of a political party?

\begin{tabular}{|c|c|c|c|c|c|}
\hline & & Frequency & Percent & Valid Percent & Cumulative Percent \\
\hline \multirow{4}{*}{ Valid } & & 4 & 1.0 & 1.0 & 1.0 \\
\hline & No & 163 & 40.8 & 40.8 & 41.8 \\
\hline & Yes & 233 & 58.3 & 58.3 & 100.0 \\
\hline & Total & 400 & 100.0 & 100.0 & \\
\hline
\end{tabular}

Source: Field survey data, $2021(\mathrm{~N}=400)$.

From the table.3, the majority of the respondents (58.3\%) described themselves as strong advocates and supporters of political parties. This is reflected in the numbers that said they were members of the tertiary wings of the two leading political parties in Ghana. 35.3\% said they belonged to the Tertiary Education Students Confederacy Network (TESCON), the tertiary education students' wing of the New Patriotic Party (NPP). Also, 29\% said they were members of the Tertiary Education Institutions Network (TEIN), the tertiary education students wing of the National Democratic Congress (NDC). This shows that young students are actively engaged in partisan activism.

\subsection{Formal Education and Partisanship}

The nexus between education and partisanship, usually, focusing on one's political knowledge, has left scholars divided (Samuels, 2006). According to Campbell (2006), schools are significant determinants in fostering strong civic norms that are enough to reduce partisan motivated analysis or interpretation of information (Campbell, 2006), although better-informed citizens are more likely to be partisan. For socialization theorists, age has a positive relationship with partisanship (Shively, 1979). Given that majority of university students are under the 
age of 30 years, their exposure to the university system could shape their intrinsic reasoning, especially when it comes to analyzing partisan issues. This has been discounted in some quarters, in the empirical literature, where education was found to rather widen peoples' partisan motives (Joslyn \& Haider-Markel, 2014).

This notwithstanding, education builds one's capacity to read before taking a position on issues. The relevance of this is that negative partisanship (that which is not in the national interest i.e. use of thugs to intimidate people) could potentially be reduced, since educated people may want to read and stay focused on the facts. Asked whether they have ever discussed, analyzed, or commented on topical political debates such as secondary education, $73.3 \%$ responded in the affirmative (Table. 4). Also, 50.8\% said they have ever discussed the election of Assembly Members, another major political issue that got the political parties divided (Table 4).

Table 4. Have you ever discussed/analyzed or commented whether in person, via traditional or social media on free senior High School Education?

\begin{tabular}{|c|c|c|c|c|c|}
\hline & & Frequency & Percent & Valid Percent & Cumulative Percent \\
\hline \multirow{4}{*}{ Valic } & & 4 & 1.0 & 1.0 & 1.0 \\
\hline & No & 103 & 25.8 & 25.8 & 26.8 \\
\hline & Yes & 293 & 73.3 & 73.3 & 100.0 \\
\hline & Total & 400 & 100.0 & 100.0 & \\
\hline
\end{tabular}

Source: Field survey data, $2021(\mathrm{~N}=400)$.

Table 5. Have you ever discussed/analyzed or commented whether in person, via traditional or social media on the proposal to elect Assembly Members?

\begin{tabular}{|c|c|c|c|c|c|}
\hline & & Frequency & Percent & Valid Percent & Cumulative Percent \\
\hline \multirow{4}{*}{ Valid } & & 5 & 1.3 & 1.3 & 1.3 \\
\hline & No & 192 & 48.0 & 48.0 & 49.3 \\
\hline & Yes & 203 & 50.8 & 50.8 & 100.0 \\
\hline & Total & 400 & 100.0 & 100.0 & \\
\hline
\end{tabular}

Source: Field survey data, $2021(\mathrm{~N}=400)$.

The above information is an indication that university education enlightens people on the need to, at least, read and be informed before taking positions on policy decisions, as part of the civic duty of elites in society. Lupu (2015) emphasized that the elites are minded of their duty to play a major role in influencing attitudes, like partisanship, which may contribute to nurturing the democratic consciousness of the masses when done in the national interest.

Motivated reasoning theorists suggest that people (especially in the western world) analyze or seek information that reinforces their preferred political party's position and oppose those that emanate from their political opponents, irrespective of the facts (Bolsen et al., 2014; Kunda, 1990; Mullinix, 2018). Some scholars hold the view that education is not the dose that can overcome partisan motives; rather education can intensify partisan motives (Joslyn \& Haider-Markel, 2014). Respondents were asked whether their education/socialization through the university system has altered the way they argue out their party's position on national issues. Interestingly, $42.8 \%$ noted that their education has influenced the way they analyze political issues while $45.3 \%$ said the opposite (Table $6)$. 
Table 6. Has your education/socialization through the university system altered the way you argue out your party's position on national issues?

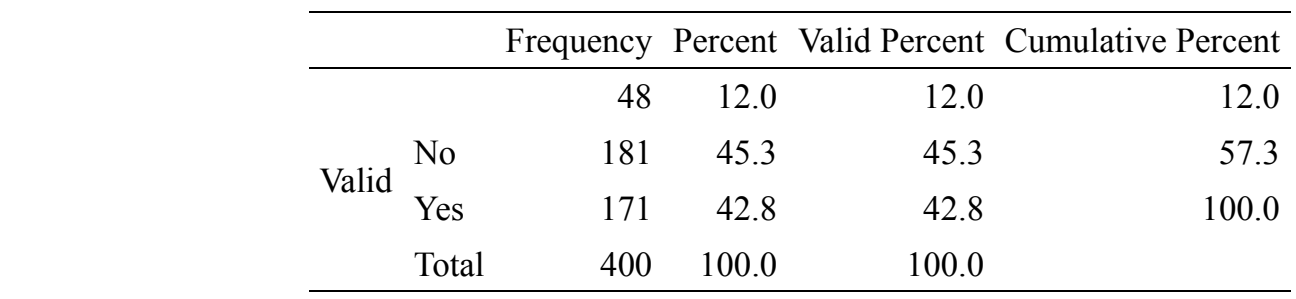

Source: Field survey data, $2021(\mathrm{~N}=400)$.

This could be interpreted to mean that Ghana has become polarized along partisan lines to the extent that many young people being educated at the university level are prepared to take positions on issues in line with the partisan positions of their preferred political parties. The implication of this is that when a political party has a diabolical view, many of the educated elites in the party will likely support that position. This does not conform to the assertion of democratic consolidation theorists (Huntington, 2012; Linz \& Stepan, 2011). It, therefore, did not come as surprise when the majority of the respondents held the view that Ghana is polarized along partisan lines. On the reasons behind the polarization, $41.5 \%$ were of the view that the political environment favours partisan polarization. Also, 26.5\% attributed it to illiteracy while rationality, defined as taking care of peoples' survival instincts, accounted for $18.8 \%$.

Table 7. Why do you think Ghanaians are polarized along partisan lines?

\begin{tabular}{lrrrrr}
\hline & Frequency & Percent & Valid & Cumulative \\
& & & Percent & Percent \\
\hline & 29 & 7.3 & 7.3 & 7.3 \\
Because of illiteracy & 106 & 26.5 & 26.5 & 33.8 \\
Because of survival instincts & 75 & 18.8 & 18.8 & 52.5 \\
Valid Others................. & 24 & 6.0 & 6.0 & 58.5 \\
The political environment favours & partisan & 166 & 41.5 & 41.5 & 100.0 \\
polarization & & 400 & 100.0 & 100.0 & \\
Total & & & & & \\
\hline
\end{tabular}

Source: Field survey data, $2021(\mathrm{~N}=400)$.

According to Clark and Wilson (1962), the activities of people in political parties can be explained by comprehending the incentive systems. This implies that people engage in a certain aspect of political participation and/or action because of perceived benefits. In this context, material incentives such as money or any other reward that can be converted into monetary value could be the motivating factors that explain political activism. Empirically, this appears to be the norm now in Ghana when the supporters of the winning party will seize public properties such as toll booths, public toilets, health insurance offices among others (Asekere, 2021; Gyimah-Boadi, 2007).

\subsection{Partisanship and Polarization}

The connection between political party polarization and partisanship is not very clear. The seemingly dominant view, however, is that partisanship leads to polarization over time (Lupu, 2015). When people are motivated by partisanship, they tend to seek out information that either reinforces their preferred political party's position or merely for political equalization (Mullinix, 2018). At the same time, they counter-argue or oppose any issue that challenges the position of the party they support, irrespective of facts. A person's exposure to a political party may be enough motivation to embrace partisan endorsements of issues that can trigger partisan distortions of information processing (Bolsen et al., 2014; Mullinix, 2018). The study found that partisan motivated respondents were supportive of their party's stands or positions on the issues the paper assessed. On the other hand, it emerged that respondents who were motivated by a sense of civic duty were less partisan in endorsing or opposing the 
issues assessed. Respondents were first asked: Would civic duty make you alter or deviate from your partisan preferences even if that would portray you as thinking along the lines of a party you do not support? It emerged that $55.5 \%$ said yes while $33.8 \%$ said no.

Table 8. Civic duty and partisanship

\begin{tabular}{|c|c|c|c|c|c|}
\hline & & Frequency & Percent & Valid Percent & Cumulative Percent \\
\hline \multirow{4}{*}{ Valid } & & 43 & 10.8 & 10.8 & 10.8 \\
\hline & No & 135 & 33.8 & 33.8 & 44.5 \\
\hline & Yes & 222 & 55.5 & 55.5 & 100.0 \\
\hline & Total & 400 & 100.0 & 100.0 & \\
\hline
\end{tabular}

Source: Field survey data, $2021(\mathrm{~N}=400)$.

Groenendyk (2013) aver that people's desire to update their partisanship in response to civic norms is progressively tenable because of the perception that conforming to civic duty is in the interest of general societal norms of pragmatism over partisanship. Given that all respondents were university students; it is quite disturbing that close to $56 \%$ are prepared to subordinate the national/civic duty to partisan interest. It is argued that "partisanship shapes policy preferences over a relatively long time, even when the political context changes" (Donald et al., 2002, p. 39). Asked if respondents would support a policy if it were proposed by their preferred political party and oppose the same issue if it were proposed by another party, $57 \%$ responded in the negative while $31.5 \%$ in the affirmative.

Table 9. If your party proposes an issue, would you support it and oppose the same issue if it were proposed by another party?

\begin{tabular}{|c|c|c|c|c|c|}
\hline & & Frequency & Percent & Valid Percent & Cumulative Percent \\
\hline \multirow{4}{*}{ Valid } & & 46 & 11.5 & 11.5 & 11.5 \\
\hline & No & 228 & 57.0 & 57.0 & 68.5 \\
\hline & Yes & 126 & 31.5 & 31.5 & 100.0 \\
\hline & Total & 400 & 100.0 & 100.0 & \\
\hline
\end{tabular}

Source: Field survey data, $2021(\mathrm{~N}=400)$.

The above responses are, therefore, in sync with the views held by Bolsen et al (2014) that one's partisan exposure determines endorsement or partisan distortion of issues. Interviewees P1 and C1 explained how their education has contributed to the manner they now analyze or interpret political information:

At first, it was easy for me to conclude on certain issues once my party supported them but I have changed. Aristotle, a philosopher, said if you hear one side of the issue and you conclude on it without reading the alternate view, it means you are empty. So yes, the university has broadened my horizons on how to independently argue with facts (P1. interview, July 20, 2021). Similarly, another noted: I can now see the difference. The University system has exposed me to the fact that it is not all that my favourite political party proposes or opposes that favours the majority of Ghanaians. Most of the decisions of the parties do not go in the interest of the ordinary Ghanaian, so now I will only support what is in the interest of the masses (C1, interview, July 21, 2021).

These views are in tandem with the theoretical assertion that objectively minded individuals consider the alternative position and conclude with the superior position based on the national interest (Tetlock \& Kim, 1987).

\subsection{Motivated Goals: Directional or Accuracy}

Political activism motivated by directional goals suggests that a person's party identification drives him/her to discuss, analyze, or interpret information that will be conclusively skewed in a partisan manner. To have accuracy goals as one's motivation, a person will discuss, analyses, or interpret political information to reach an accurate outcome devoid of partisan interest (Taber and Lodge, 2006). The researchers used two topical programmes that have attracted the headlines and dominated public discourse between 2014 and 2020. The first was free Senior High School education and the second was the election of Assembly Members. Per the official campaign manifesto 
of the NPP and NDC, on second cycle education, the NPP was emphatic that it will implement wholesale free education at the second cycle level, irrespective of challenges including cost and infrastructure. The NDC had started the implementation of what it called progressively free education at the second cycle level with selected day schools on a pilot basis but maintained that the policy will be implemented after enough infrastructure had been put in place. The NDC (as the then governing party) had begun the construction of 200 community secondary schools, which it claimed was in line with the programme. On the second issue of Local Government elections, both parties in their official documents agreed to elect Metropolitan, Municipal, and District Chief Executives (MMDCEs). The NPP won the 2016 elections and set the ball rolling so both parties supported the idea of electing MMDCEs. Despite the initial disagreements, both parties agreed to elect MMDCEs on a partisan basis. When plans were ripped for a referendum, as per the dictates of Ghana's constitution, the governing party added the election of Assembly Members on partisan lines. The NDC strongly opposed it and asked its supporters to do the same. Fearing a possible defeat, the President suspended the exercise. These are the facts. Public commentary, however, has been based on distortions of the issues.

Given the above, the researchers sought the views of university students to ascertain whether or not they are also engaged in distorted information based on partisan attachment. Respondents were first asked their source of information to determine whether they rely on authentic sources. It emerged that majority of the respondents relied on social media for information followed by official political party websites and releases (Figure 1).

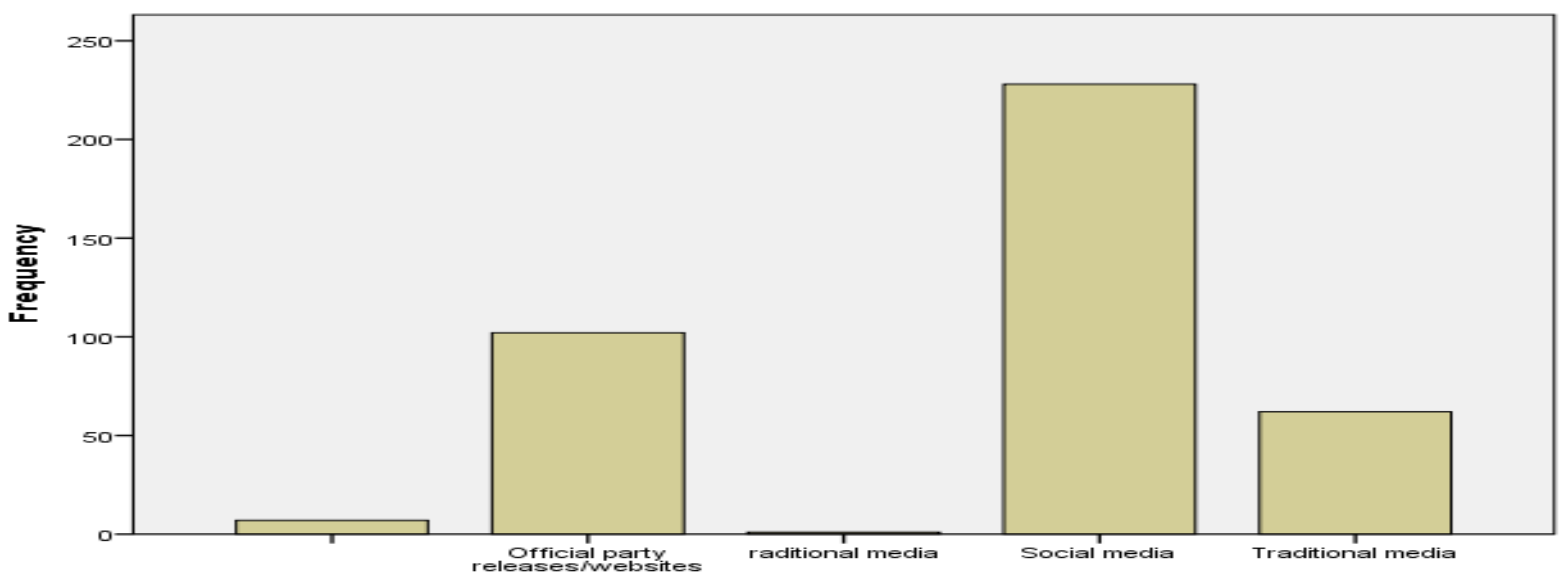

Figure 1. Bar chart showing the sources of information for respondents

Source: Field survey data, $2021(\mathrm{~N}=400)$.

In Ghana, social media is full of distorted information because of its unregulated nature. The state media has also virtually been used as the mouthpiece of the governing party, raising issues of authenticity, trustworthiness, and credibility. Besides, the tilted media ownership has led to a situation where information on traditional media reflects the political views of the owners. As such very few media houses are trusted for reliable information (Dzisah, 2018; Gyampo, 2017; Shardow \& Asare, 2016). In this circumstance, the only trusted source of reliable information on political parties is the parties' official websites or documents. Unfortunately, majority of university students admitted to relying on social media for information. The challenge with this is that many people are at the risk of analyzing, commenting, or processing distorted information. This certainly will have an impact on the eventual position since you don't plant maize and expect to harvest tomatoes. It emerged that $73.3 \%$ and $50.8 \%$ of respondents admitted that they had read the positions of the NPP and NDC on free senior high school education and elections of Assembly Members, respectively (see tables 4 and 5).

The researchers engaged some respondents who described themselves as being strong members and advocates of the NPP and NDC in further interviews. They also confirmed being active members of the tertiary education students' wings of the two parties. Besides, they also said that they read the two political parties' policy positions on the issues under scrutiny. They were asked open-ended questions on the NPP and NDC's positions on free Senior School education and the election of Assembly Members. The NPP members/advocates are designated P1P5 while the NDC's are designated C1-C5.

Asked, what were the NPP and NDC's respective positions on free Senior High School. The following responses were gathered: 
A respondent noted that NPP's position on the subject was that: every child must access secondary education freely regardless of his/her background and it must start on a wholesale basis. This will enable all the youth to get access to secondary education. The NDC on the other hand was of the view that free SHS was not financially feasible, hence they believed in progressive free SHS. Also, when eventually implemented, individuals should be made to pay their wards school fees because some people are capable enough to take care of their children (P1, interview, July 20, 2021). This respondent's view falls under the directional goal because he accurately stated the position of his party (NPP) and distorted the NDC's position by adding that the NDC's view was to have parents pay fees for the wards even when free SHS was implemented. Probed on the source of his information, he cited the parties' official websites. The implication is that either he lied about the source or he deliberately distorted the facts to favour his party.

Another respondent opined that the: NPP wanted free compulsory SHS to begin by redefining senior high school to include basic schools and under this, each student shall be entitled to a hot meal. 'The NDC also supported the Free SHS in a way, but they thought of infrastructure first. They believed that per Ghana's constitution, the free SHS is supposed to be progressive, hence it should be given a second thought (P2, interview, July 20, 2021). This view fairly reflects the position of the two parties, hence falls under accuracy goals. The researchers noted that either the source of information from this respondent, which was official party websites, contributed to factual responses or he was motivated by his civic duty and independent-mindedness.

Similarly, another respondent stated that: The NDC proposed that the free SHS must be done progressively. Starting from developing infrastructure then eventually the free SHS takes place in bulk. In effect, the NDC preferred quality education progressively instead of making it free at ago amidst challenges of accessibility. The NPP's position was that secondary school should be free for everyone so that we would get a lot of people in the country having SHS certificates. Also, the government will cover all the bills for students so that when they grow, they will support the party $(C 1$, interview, July 21, 2021). This respondent was also motivated by a directional goal, by distorting the information on the NPP's position when he added that the ultimate goal was to have beneficiaries join or support the NPP. Meanwhile, he clearly stated the correct position of the NDC which he said is the party he strongly supports.

Another respondent who aligns herself with the NPP noted as follows: The NPP wanted to implement free SHS to give access to secondary education to all persons in Ghana. Also, accessibility to all irrespective of impending challenges which are less compared to the price of a future illiterate population. The NDC described the free SHS policy as unrealistic and 'sakawa' because they realized the country was not solvent enough to roll out a programme ((P3, interview, July 18, 2021). Again this respondent distorted the information by stating factually inaccurate views about the NDC and the correct views about the NPP. She was motivated by partisan or directional interest. She cited traditional media as the source of her information.

An NDC member and advocate stated that: For the NDC, it makes sense to progressively implement free SHS as they did in 2015/2016 by first absorbing examination, library SRC, science laboratory, and cultural fees for over 100,000-day students in public secondary schools. The party also built 200 new senior high schools across the country especially in areas without schools to solve the problem of accessibility, hence was ready to have a holistic free SHS implemented in the shortest possible time. The NPP's position was to offer free education to all Ghanaian citizens who qualify to be educated in the Senior High Schools opportunity by paying for all bills in other not to deprive the poor of their right to be educated. Through this social intervention project, access to education could be improved (P3, interview, July 18, 2021). This assertion is correct hence motivated by civic duty or accuracy goals. He cited traditional media and official party releases are the source of his information. This means that the respondent made extra effort to get the facts, which is a core function of educated partisans (Joslyn \& HaiderMarkel, 2014).

Also, a respondent aligned to the NDC noted: The NDC's position was that free SHS should not be implemented under whimsical promises of a desperate politician, and that, there must be a progressive introduction of free SHS as required by the constitution of Ghana. This should be achieved by first expanding infrastructure to curtail its foreseeable anomalies. The NPP, for their part, just said they will implement free SHS to reduce unemployment in Ghana (C3, interview, July 25, 2021). This was also distorted in favour of the NDC. While he rightly stated the NDC's position, he distorted the NPP's position on the programme. He mentioned social and traditional media as the source of his information.

Similar, observations were observed when the respondents were asked open-ended questions on the election of Assembly Members.

One noted that: the NPP advocated for the election of the Assembly Members. However, this was rejected by the 
opposition NDC on the basis that there was no money (P4, interview, July 22, 2021). Another remarked: The NPP proposed that assembly members should be elected on neutral grounds without political parties but the NDC just opposed it (P5, interview, July 23, 2021). Both P4 and P5 distorted the position of the NDC. Also, while P4 got the position of his part right, P5 got it wrong. Both said they relied on social media for their information.

An advocate of the NDC said: the NPP wanted the status quo maintained to deepen decentralization in Ghana. They should be voted on a partisan basis but they should be non-partisan in the performance of their duty. The $N D C$, on the other hand, said the election of Assembly Members should be done on non-partisan lines to prevent political divisions at the local level (C4, interview, July 16, 2021). This respondent equally distorted the position of the NPP and accurately stated the views of the NDC. She cited official party websites as the source of her information. As such, it could be argued that she was motivated by directional or partisan goals. Some people simply distorted the two parties' official positions on the elections of Assembly Members. One of such noted: the NPP was of the notion that the Metropolitan, Municipal, and District Chief Executives should be sponsored by parties, meaning they should have a line of affiliation to a political party to enhance quick development. For assembly Members, the NPP said they should be paid monthly. The NDC was against the election of Assembly Members because developments at the district level, which form part of the local government structure, will most likely be stagnated if a governing party has an opposition Assembly Member (C5, interview, July 16, 2021). This respondent distorted the position of both parties. According to her, social media was the source of her information. The sources of information cited by the interviewees reflect those of survey respondents (see figure 1).

This data is in sync with the view that the source or people's access to political party information does not improve young people's judgment but rather media information does (Kahne \& Bowyer, 2017). Also, the interviewees who distorted the information in favour of their political parties in a partisan manner conform with the survey respondents who claimed that despite their education, they will oppose policies proposed by their political opponents and endorse the same policies if proposed by their political parties.

\section{Conclusion and Recommendations}

The scholarship on the effect of education and parochial partisanship that leads to political polarization presents rebuts findings on healthy multi-party democratic regimes. This paper sought to contribute and extend the literature by exploring a much less considered area, that is, university education's influence on mitigating parochial partisanship which does not inure to peace and democratic stability. The underlying assumption in this paper was that when there is political polarization as a result of growing parochial or negative partisanship, because of a higher rate of illiteracy, exposure to university education will inculcate in young people a sense of civic duty to dampen parochial partisanship to help the cause of democratic development. This was explored using Taber and Lodge's (2006) criterion for motivated opinion formation in party politics namely, directional and accuracy goals. The former suggests that irrespective of education, young people will remain partisan even if it leads to polarization, and for this paper, dents the progress of Ghana's democracy. The latter assumes that exposure to university education will reverse or minimize any parochial partisanship that could lead to polarization because of the sense of civic duty that education provides.

The findings show that university education is a necessary but not sufficient condition to curtail partisanship that leads to polarization in Ghana. University students who join political parties, largely, think along with the partisan position of their political parties, irrespective of education. This, notwithstanding, university education in Ghana has enlightened many young people to prioritize reading to decipher between the facts and the propagandistic view held by political party activists because of their parochial partisan interest. The paper, therefore, concludes that even though education empowers young people to think independently, it does not stop polarization caused by partisan-driven shifting political party policies. In effect, university education has not taken away parochial partisanship among Ghanaian students. The tilt, therefore, remains largely directional which is not towards civic duty. This does not auger well for a country that aims at mitigating the problem of political polarization and consolidating its democracy.

The paper recommends the following: First, the winner-takes-all politics being practiced in Ghana should be reviewed. Second, periodic educational seminars on the effects of negative partisanship should be undertaken by officials of both the NDC and NPP across all tertiary educational institutions. Third, nationwide civic education fora should be held by the National Commission for Civic Education (NCCE) and the Information Services Department, to educate the masses on the need for political tolerance.

\section{Acknowledgement}

Funds for this research came from Government of Ghana's annual allowance to lecturers in Ghana to carry out academic research. 


\section{References}

Abotsi, E. K. (2013). Rethinking the Winner-Takes-All System. A Constitutional Review Series Roundtable Organized by the IEA in Accra on 21st August.

Adzimah-Alade, M., Akotia, C. S., Annor, F., \& Quarshie, E. N.-B. (2020). Vigilantism in Ghana: Trends, victim characteristics, and reported reasons. The Howard Journal of Crime and Justice. https://doi.org/10.1111/hojo.12364

Alhassan, A., Odartey-Wellington, F., \& Shaibu, A.-F. (2019). Civil Society Actors and Broadcast Media Muzzling in Ghana's Northern Region. Covenant Journal of Communication, 6(2).

Alidu, S., \& Aggrey-Darkoh, E. (2018). Rational voting in Ghana's 2012 and 2016 National Elections in perspective. Ghana Social Science, 15(1), 98.

Amponsah, N., \& Boafo-Arthur, K. (2002). Ghana's Democratic Renaissance: An Overview. Local Government in Ghana Grassroots Participation in The, 1-17.

Asamoah, K. (2020). Addressing the problem of political vigilantism in Ghana through the conceptual lens of wicked problems. Journal of Asian and African Studies, 55(3), 457-471. https://doi.org/10.1177/0021909619887608

Asekere, G., \& Braimah, A. I. (2021). Leadership and Women Representation Riddle in Ghana. American Journal of Educational Research, 9(4), 169-179. https://doi.org/10.12691/education-9-4-4

Asekere, G. (2021). Study on Domesticating Vigilantism in Ghana's Fourth Republic: The Challenge Ahead. In Hus, V. (Eds.), Modern Perspectives in Language, Literature and Education (Vol. 5, pp. 55-71). Hong Kong: BP International. https://doi.org/10.9734/bpi/mplle/v5/2315E

Ayee, J. R.A. (1990). The implementation of the 1988/89 district assembly (local government) elections in Ghana. Africa Insight, 20(3), 169-175.

Bauer, G. (2019). Ghana: Stalled Patterns of Women's Parliamentary Representation. In The Palgrave Handbook of Women's Political Rights (pp. 607-625). Springer. https://doi.org/10.1057/978-1-137-59074-9_41

Blais, A. (2000). To vote or not to vote?: The merits and limits of rational choice theory. University of Pittsburgh Pre. https://doi.org/10.2307/j.ctt5hjrrf

Blanc, T. A. (2008). Terms of engagement: Civic and political behavior among Arizona youth. Arizona State University.

Bob-Milliar, G. M. (2012). The Dynamics of Political Party Activism in Ghana: A Comparative Study of the Activists of the NDC and NPP in Wa Centraland Lawra-Nandom Constituencies, (1992-2008). [Ph.D. Thesis]. University of Ghana.

Bob-Milliar, G. M. (2014). Party youth activists and low-intensity electoral violence in Ghana: A qualitative study of party foot soldiers' activism. African Studies Quarterly, 15(1), 125.

Bolsen, T., Druckman, J. N., \& Cook, F. L. (2014). The influence of partisan motivated reasoning on public opinion. Political Behavior, 36(2), 235-262. https://doi.org/10.1007/s11109-013-9238-0

Campbell, A., Gurin, G., \& Miller, W. E. (1954). The voter decides.

Campbell, D. E. (2006). Why we vote: How schools and communities shape our civic life (Vol. 100). Princeton University Press.

Clark, P. B., \& Wilson, J. Q. (1961). Incentive systems: A theory of organizations. Administrative Science Quarterly, 129-166. https://doi.org/10.2307/2390752

Costantini, E., \& King, J. (1984). The motives of political party activists: A factor-analytic exploration. Political Behavior, 6(1), 79-93. https://doi.org/10.1007/BF00988230

Creswell, J. W. (2014). A concise introduction to mixed methods research. Sage Publications.

Creswell, J. W., \& Creswell, J. D. (2017). Research design: Qualitative, quantitative, and mixed methods approaches. Sage publications.

Dalton, R. J. (2008). Citizenship norms and the expansion of political participation. Political Studies, 56(1), 76 98. https://doi.org/10.1111/j.1467-9248.2007.00718.x

Dar, L., \& Lee, D.-W. (2014). Partisanship, political polarization, and state higher education budget outcomes. The Journal of Higher Education, 85(4), 469-498. https://doi.org/10.1353/jhe.2014.0023 
Debrah, E., Alidu, S., \& Owusu-Mensah, I. (2016). The Cost of Inter-Ethnic Conflicts in Ghana's Northern Region: The Case of the Nawuri-Gonja Conflicts. Journal of African Conflicts and Peace Studies, 3(1), 2. https://doi.org/10.5038/2325-484X.3.1.1068

Debrah, E., \& Van Gyampo, R. E. (2013). The youth and party manifestos in Ghanaian politics-the case of the 2012 general elections. Journal of African Elections, 12(2), 96-114.

Denzin, N. K., \& Lincoln, Y. S. (2005). Introduction: The discipline and practice of qualitative research.

Donald, G., Palmquist, B., \& Schickler, E. (2002). Partisan hearts and minds. New Haven, CT: Yale University Press.

Druckman, J. N. (2012). The politics of motivation. Critical Review, 24(2), 199-216. https://doi.org/10.1080/08913811.2012.711022

Druckman, J. N., Peterson, E., \& Slothuus, R. (2013). How elite partisan polarization affects public opinion formation. American Political Science Review, 107(1), 57-79. https://doi.org/10.1017/S0003055412000500

Dzisah, W. S. (2018). Social media and elections in Ghana: Enhancing democratic participation. African Journalism Studies, 39(1), 27-47. https://doi.org/10.1080/23743670.2018.1452774

Emile Short Commission of Inquiry Report (2020). Available on https://www.adomonline.com > Politics. Full gov't White Paper on Short Commission report. Accessed on 24/06/2020.

Goren, P., Federico, C. M., \& Kittilson, M. C. (2009). Source cues, partisan identities, and political value expression. American Journal of Political Science, 53(4), 805-820. https://doi.org/10.1111/j.15405907.2009.00402.x

Groenendyk, E. (2013). Competing motives in the partisan mind: How loyalty and responsiveness shape party identification and democracy. Oxford University Press. https://doi.org/10.1093/acprof:oso/9780199969807.001.0001

Gyampo, R. E. V. (2015). Dealing with Ghana's winner-takes-all politics: The case for an independent parliament. A Publication of the Institute of Economic Affairs, 21(3).

Gyampo, R. E. V. (2017). Social media, traditional media and party politics in Ghana. Africa Review, 9(2), 125139. https://doi.org/10.1080/09744053.2017.1329806

Gyimah-Boadi, E. (2007). Political parties, elections and patronage: Random thoughts on neo-patrimonialism and African democratization.

Huntington, S. P. (2012). The third wave: Democratization in the late 20th century (Vol. 4). University of Oklahoma Press.

Israel, G. D. (1992). Determining sample size. Gainesville, FL: University of Florida.

Joslyn, M. R., \& Haider-Markel, D. P. (2014). Who knows best? Education, partisanship, and contested facts. Politics \& Policy, 42(6), 919-947. https://doi.org/10.1111/polp.12098

Kahne, J., \& Bowyer, B. (2017). Educating for democracy in a partisan age: Confronting the challenges of motivated reasoning and misinformation. American Educational Research Journal, 54(1), 3-34. https://doi.org/10.3102/0002831216679817

Kunda, Z. (1990). The case for motivated reasoning. Psychological Bulletin, 108(3), 480. https://doi.org/10.1037/0033-2909.108.3.480

Linz, J. J., \& Stepan, A. (2011). Problems of democratic transition and consolidation: Southern Europe, South America, and post-communist Europe. JHU Press.

Lippman, W. (1993). The Phantom Public. New Brunswick. NJ: Transaction Publishers.

Lupu, N. (2015). Party polarization and mass partisanship: A comparative perspective. Political Behavior, 37(2), 331-356. https://doi.org/10.1007/s11109-014-9279-z

Mahoney, J., \& Goertz, G. (2006). A tale of two cultures: Contrasting quantitative and qualitative research. Political Analysis, 14(3), 227-249. https://doi.org/10.1093/pan/mpj017

Miller, A. H., \& Klobucar, T. F. (2000). The development of party identification in post-Soviet societies. American Journal of Political Science, 667-686. https://doi.org/10.2307/2669274

Mullinix, K. J. (2018). Civic duty and political preference formation. Political Research Quarterly, 71(1), 199214. https://doi.org/10.1177/1065912917729037 
Samuels, D. (2006). Sources of mass partisanship in Brazil. Latin American Politics and Society, 48(2), 1-27. https://doi.org/10.1111/j.1548-2456.2006.tb00345.x

Shardow, M. S., \& Asare, B. E. (2016). Media ownership and independence: Implications for democratic governance in the fourth republic of Ghana. Journal of Pan African Studies, 9(9).

Shively, W. P. (1979). The development of party identification among adults: Exploration of a functional model. American Political Science Review, 73(4), 1039-1054. https://doi.org/10.2307/1953988

Strömblad, P., \& Bengtsson, B. (2017). Collective Political Action as Civic Voluntarism: Analysing Ethnic Associations as Political Participants by Translating Individual-level Theory to the Organizational Level. Journal of Civil Society, 13(2), 111-129. https://doi.org/10.1080/17448689.2017.1302912

Taber, C. S., Cann, D., \& Kucsova, S. (2009). The motivated processing of political arguments. Political Behavior, 31(2), 137-155. https://doi.org/10.1007/s11109-008-9075-8

Taber, C. S., \& Lodge, M. (2006). Motivated skepticism in the evaluation of political beliefs. American Journal of Political Science, 50(3), 755-769. https://doi.org/10.1111/j.1540-5907.2006.00214.x

Tetlock, P. E., \& Kim, J. I. (1987). Accountability and judgment processes in a personality prediction task. Journal of Personality and Social Psychology, 52(4), 700. https://doi.org/10.1037/0022-3514.52.4.700

Warren, M. E. (2001). Democracy and association. Princeton University Press.

Whiteley, P. F., \& Seyd, P. (2002). Theories of participation and High-intensity participation. High-Intensity Participation: The Dynamics of Party Activism in Britain, 35-57. https://doi.org/10.3998/mpub.14704

Yin, R. K. (2006). Mixed methods research: Are the methods genuinely integrated or merely parallel. Research in the Schools, 13(1), 41-47.

\section{Appendix 1. Data collection instrument}

\section{Dear Respondent,}

This survey is aimed as assessing the interplay between political participation, civic involvement, and partisan information processing among university students in Ghana. Be assured that the information provided for this research is purely for academic purposes and will be treated with the utmost confidentiality it deserves.

\section{DEMOGRAPHIC INFORMATION}

1. Sex (a) Male (b) Female
2. Age
(a) $18-24$
(b) $25-30$
(c) $31-35$
(d) $36-40$
(e) $41+$

3. Religion (a) Christianity (b) Islam (c) Traditional Religion (d) Non-Religious (e) other

\section{Level of Education}
a. 100
b. 200
c. 300
d. 400
e. Masters

\section{PARTY MEMBER DYNAMICS}

1. Are you a member, supporter or sympathizer of a political party?
a. Yes
b. No

2. If yes, which of the political parties?
a. NPP
b. NDC
c. $\mathrm{CPP}$
d. PPP 
e. Others

3. Do you consider yourself a strong advocate/supporter of a political party?
a. Yes
b. No

4. If yes, which of the political parties?
a. NPP
b. NDC
c. Others

5. Which of the tertiary wings of the political parties do you belong to?
a. Tescon
b. Tain
c. Others.

6. Have you ever discussed/analyzed or commented whether in person, via traditional or social media on the proposal to elect Assembly Members?
a. Yes
b. No

7. Have you ever discussed/analyzed or commented whether in person, via traditional or social media on free senior High School Education?
a. Yes
b. No

8. Did you read the two parties' positions on Free SHS and the election of Assembly members?
a. Yes
b. No

9. What is your main source of information on political party decisions?
a. Traditional media
b. Social media
c. Official party releases/websites

10. What was the NPP's position of free SHS?

11. What was the NDC's position of free SHS?

12. What was the NPP's position in the election of Assembly Members?

13. What was the NDC'S position on the election of Assembly Members? 
14. Has your education/socialization through the university system altered the way you argue out your party's position on national issues?
a. Yes
b. No

15. If yes, how?

16. Do you process/present/discuss political information based on your party's position?
a. Yes
b. No

17. Do you process/present/discuss political issues based on your civic duty as an independent young analyst or do you believe your party's position represents that civic/national interest?
a. I think independent of my party
b. I think based on my party's position

18. Do you believe that most political issues are analyzed with propagandistic considerations?
a. Yes
b. No

19. If your party proposes an issue, would you support it and oppose the same issue if it were proposed by another party?
a. Yes
b. No

20. Would civic duty alter or deviate from your partisan preferences even if that would portray you as thinking along the lines of a party you do not support?
a. Yes
b. No

21. Many people hold the view that the NDC and NPP are the same coin with different faces hence, the political equalization in a partisan nature, on virtually every issue. How do you agree with such?
a. Yes
b. No

22. Do you agree that Ghana is polarized along partisan lines?
a. Yes
b. No

23. What do you think Ghanaians are polarized along partisan lines?
a. Because of illiteracy
b. Because of survival instincts
c. The political environment favours partisan polarization
d. Others

\section{Copyrights}

Copyright for this article is retained by the author(s), with first publication rights granted to the journal.

This is an open-access article distributed under the terms and conditions of the Creative Commons Attribution license (http://creativecommons.org/licenses/by/4.0/). 